\title{
CHINA VS VIETNAM : AN ANALYSIS OF HOW CHINA LOST ITS COMPARATIVE ADVANTAGE TO VIETNAM
}

\author{
JATIN BHATNAGAR ${ }^{1}$, PUNEET BHATNAGAR ${ }^{2}$ and SATVIK RASTOGI ${ }^{3}$ \\ ${ }^{1,3}$ Delhi Technological University, New Delhi, Delhi 110016, India \\ ${ }^{2}$ Christ University, Lavasa, Maharashtra 412112, India
}

DOI: 10.46609/IJSSER.2021.v06i07.013 URL: https://doi.org/10.46609/IJSSER.2021.v06i07.013

\begin{abstract}
The purpose of this research is to analyse the reasons behind China's loss of comparative advantage to Vietnam in the technology sector, its implications at economic and social level and to understand what it means for the Chinese economy in the global scenario.

For the purpose of this research, we have collected data on exports/imports between Vietnam and China along with Vietnam and United States of America. We are going to analyse how China's dumping policy combined with Vietnam's improvement in the following dimensions: ease of doing business, educated human resource and FDIs in Vietnam from China and the United States.

The main aim of this research to analyse the impact of dumping on comparative advantage. For this purpose, we are going to run a regression analyse to analyse the correlation between export from China to US and the quantity of exports from Vietnam to US before/during/after the antidumping laws administered by the Trump government.

Through our research, we concluded that the quantity of exports met a negative trend in China and a positive trend in Vietnam during the sanction period. Moreover, there was significant negative correlation between the two variables which, in turn, points to the transfer of comparative advantage from China to Vietnam.

This comparative advantage was short-lived as the exports of China got back on-track after the removal of sanctions. However, this rise in Chinese exports did not negatively affect the Vietnamese exports to the United States of America. Moreover, there was significant positive correlation between the two trends during the year 2019 which in turn states that the intensity of positive correlation between the two variables throughout the year outshined the negative correlation between the two variables during the sanction period.
\end{abstract}

Key words: China, Vietnam, WTO, Comparative advantage, international trade. 


\section{International Journal of Social Science and Economic Research}

ISSN: $2455-8834$

Volume:06, Issue:07 "July 2021"

\section{Literature Review}

1. British economist David Ricardo, published his book On the Principles of Political Economy and Taxation in 1817 and presented his "Theory of Comparative Advantage," which has remained fundamentally unchallenged until today. Moreover, David Ricardo has also defended the advantages of free trade for Britain in his work "Theory of Corn Law."

2. Empirical tests on comparative advantage have been conducted by various economists such as (Kenen, 1965 and 1970; Keesing, 1965 and 1966; Krueger, 1968; Deardoff, 1984; Golub and Hsieh, 2000; Kowalski, 2011; Costinot et al., 2012).

3. Despite this multiplication of the empirical tests on the comparative advantage principle, their importance in explaining the current trade flows is steadily falling, so that Wood (1994) recognizes the need to give a chance to Heckscher and Ohlin approach. In reality, the results of the empirical tests on the principle of comparative advantage are not definitive.

4. In a research paper published by the Institute of World Economy, Kiel, on the topic of "The Impact of the US - China Trade" investigates the potential indirect effects of tariff hikes in the recent US-China trade war on other trading partners. Researchers Haiou Mao and Holger Görg argue, “...because of close trading relationships, the US, the EU, Canada and Mexico are hit hardest in absolute terms by increased US tariffs on Chinese imports. We estimate that the tariffs impose an additional burden of between 500 million to 1 billion US dollars on these two countries. The EU is also heavily affected. The impact of China's tariffs on US imports is much lesser. This shows that third countries are not unaffected by trade."

5. Z. Suisheng and D. Guo have done a detailed research on the causes and impact of the trade war between United States of America and China. Through their research, they have concluded that the current economic climate is that of a modern-day cold war.

6. Rafi Sheikh studies the US trade war with China and asks whether it is possible to win this war. According to their research, every trade war recognizes three losers: the two nations involved in trade and the global decline in trade, leading to a slowdown in the global economic growth.

7. Carnegie addresses the issue of the escalation of Trump's trade war, Grossman and Helpman turn their attention to the issue of trade war and trade negotiations. Moreover, the current US-China trade war also involves negotiations which have led to many concessions (most of them from relatively highly protected Chinese market).

8. Chunding, Chuntian, and Chungwei address the economic impact of a possible trade war.

9. In his article, Bouët asks whether trade wars are beneficial and whether they can be easily won. 
International Journal of Social Science and Economic Research

ISSN: 2455-8834

Volume:06, Issue:07 "July 2021"

10. Vinogradov, Salitsky and Semenova have noted that Chinese companies have already begun to move production units to Vietnam, Bangladesh, Ethiopia and other countries with relatively cheap labour, given the fact that a large percentage of Chinese exports constitute products of TNCs that have placed final assembly production units in the PRC.

\section{Introduction}

\section{What exactly is a trade war?}

Trade war is a phenomenon that happens when a nation imposes tariffs or quotas on imports from foreign countries, in order to protect the domestic industries and to create jobs. In return the foreign countries retaliate with their own trade restrictions and tariffs. As the condition worsens, a trade war reduces international trade.

In the short run, it may work. The objective for the tariffs is to give a comparative advantage to local producers. Their prices would be lower by comparison. Consequently, more buyers shift to local products and the businesses grow, which leads to more employment.

In the long run however, a lot of jobs are lost. Due to globalization, all of the economies are deeply interconnected today, hence the waves are felt all over the world. It also leads to inflation when tariffs increase the prices of imports.

A great example for trade wars is the 1930 Smoot-Hawley Tariff, which are known for worsening the great depression. Smoot-Hawley was designed to help support the U.S. farmers who had been devastated by the infamous dust bowl. Dust bowl was a natural disaster that disrupted the Midwest in the 1930's. It was the worst draught faced by North America in a 1000 years. Consequently, it also raised food prices for Americans who were already suffering from the Great Depression. Other countries countered by coming up with their own tariffs. International trade got reduced by $65 \%$. It was an economic catastrophe that turned a period of recession into one of depression and started a domino effect that led to World War II.

\section{The US-China trade war}

International trade has witnessed a lot of changes since the beginning of $21^{\text {st }}$ century. China has emerged as a behemoth economic power while us has seen a decline in its global production and international trade. According to evaluations by Chinese scientists, china surpassed us in terms of national economic power in 2014, yet some econometric models indicate that us is still in the lead. Hence it is ambiguous to say which economic superpower is the clear winner.

During the 2016 us presidential elections, then president elects Donald trump's entire campaign was focused on trade relations of us with china. In a statement he harshly criticized the trade deficit of us with china and called it "the greatest theft in the history of the world". Further he 


\section{International Journal of Social Science and Economic Research}

ISSN: $2455-8834$

Volume:06, Issue:07 "July 2021"

accused china of unfair trading practices, including intellectual property theft, forcing international companies to share their trade secrets, lack of market access for American companies in China and an unleveled playing ground caused by Beijing's subsidies for to state owned companies.

Trump's main motivation behind initiating the trade war was to reduce the US trade deficit. Us trade deficit has been the world's largest since 1975. It was part of trump's strategy to increase more jobs in the economy. Most of that deficit came from U.S.'s craze for importing consumer goods and European automobiles. For example, in 2019, the deficit was $\$ 577$ billion. The imports amounted to goods and services worth $\$ 3.1$ trillion while exports were of $\$ 2.5$ trillion. These imported goods include many household items like televisions and clothing, pharmaceuticals and automobiles.

3 months after getting elected as the president, trump met with Chinese President Xi Jinping at the mar-a-largo, where both of them came up with a 100 day action plan to reduce trade differences. As per the agreement, china agreed to give U.S. companies greater access to its agriculture, energy and markets in exchange for U.S. recognition of its belt and road initiative. Despite reaching the agreement, both parties very soon started exchanging threats to increase tariffs. The 100 days concluded with no agreement and no joint statement in July 2017.

The trade war officially started on March 23, 2018 with trump signing a presidential memorandum targeting china's economic aggression and announcing tariffs on steel and aluminum. Initially, on January 22, 2018 Trump imposed tariffs on washing machines and solar panels. China is world's largest supplier of solar panels. Then, on March 8th Trump ordered 25\% tariffs on steel imports and $10 \%$ tariffs on aluminum on all of its suppliers and not just china. On April 2, china retaliated with its own $25 \%$ tariffs on 128 U.S. products which included soybeans and airplanes. This tariff fight went on for quite some while.

The 3 tariffs imposed by trump administration on Chinese imports amounted to $\$ 250$ billion in Chinese imports. It was estimated by the Federal Reserve that these tariffs cost the average us household $\$ 414$ per year. Then on May 10, 2019 trump imposed a $4^{\text {th }}$ tariff. He raised the rates on tariffs to $25 \%$ on $\$ 200$ billion worth of goods. The fed estimated the revised cost on us households to be $\$ 831$ per year.

On June 1, 2019 china fought back with 25\% tariff on U.S. goods worth $\$ 60$ billion. This tariff war continued to escalate until an agreement was reached for a phase one deal between the two countries in mid-December of 2019. Finally, on $15^{\text {th }}$ January 2020, the phase one trade deal was formally signed which was due to take effect on $15^{\text {th }}$ February 2020 . As part of the deal china promised to buy $\$ 200$ billion worth of U.S goods over two following years. China also removed 


\section{International Journal of Social Science and Economic Research}

ISSN: $2455-8834$

Volume:06, Issue:07 "July 2021"

barriers on a long list of us exports. In return US suspended 15\% tariff on around \$162 billion worth of Chinese goods.

In the end, the trade wars between us and china did more harm to the U.S economy and barely any good. More importantly, the economic concerns which were meant to be resolved by these trade wars still remain at large. Trade wars are never good in the long run, and both the sides felt the economic pain. According to a study by Moody's, the trade war cost U.S 300,000 jobs and $0.3 \%$ of real GDP. Another report by Bloomberg economics claims that the trade war would cost $\$ 316$ billion to the U.S, economy. While research from the federal reserve bank of New York and Columbia points at that, many U.S. companies collectively lost $\$ 1.7$ trillion of their share price due to the tariffs imposed by trump on china.

In heather long's words at the Washington post, 'U.S. economic growth slowed, business investment froze, and companies didn't hire as many people. Across the nation, a lot of farmers went bankrupt, and the manufacturing and freight transportation sectors have hit lows not seen since the last recession. Trump's actions amounted to one of the largest tax increases in years."

\section{After affects and dumping}

In international trade, dumping happens when a country exports a good at a price lower than its domestic price. For example, let's assume, china is exporting pencils to America. Due to lower standards of living in china, the price for producing the pencils will also be lower compared to United States. Hence, Chinese companies will be in a position to sell the pencils at a lower rate than American companies. Most of the American customers won't be willing to buy American pencils at higher prices when much cheaper Chinese pencils are available.

In the short run it may seem that it is not profitable for the Chinese companies to sell at price lower than the market equilibrium, but sooner or later, with entry of more Chinese companies in the market and exit of American companies, in the long run, there will be a transition in the market which will allow the Chinese markets to dominate the markets and set their own prices.

In 2014, the Commerce Department found that china's photovoltaic imports were violating the antidumping duty law by selling solar panels in the United States at prices which were far lower than the market price. In the report by the commerce department, it was found that the Chinese dumping rates ranged from $26.1 \%$ to $165.04 \%$. In addition, it was found out that china violated the countervailing duty law by providing heavy subsidies to Chinese solar manufacturers. It was one of the major factors that led to the trade war.

After the imposition of tariffs on steel imports by the trump administration, china started to diverge its steel to developing economies. There was a surge in steel imports by developing economies. For instance, steel imports to India increased by 67\% in April-May as a direct result 
International Journal of Social Science and Economic Research

ISSN: 2455-8834

Volume:06, Issue:07 "July 2021"

of the trade tariffs. India is not the only one facing steel dumping, take Vietnam for example, the Vietnamese government had to impose anti-dumping duties on stainless steel coil and sheet from china. Steel imports from china reached 272,073 tons during September 2020. Due to such sharp increase in imports, the domestic manufacturing sector is facing many problems as their profits, inventory and market share has gone down.

\section{Comparative advantage}

Comparative advantage is when a country provides a good or service for a lower opportunity cost than other countries. Opportunity cost measures a trade-off. A nation with a comparative advantage makes the trade-off worth it. The benefits of buying its good or service outweigh the disadvantages. The country may not be the best at producing something. But the good or service has a low opportunity cost for other countries to import.

For example, India has a comparative advantage when it comes to call centers, usa imports this service from india since it way cheaper to import it. Even though sometimes there may be a communication barrier due to a difference in accents, us still imports this service because the pros outweigh the cons.

China has a similar competitive advantage due to cheap labor and heavy subsidies by the government, when it comes to manufacturing. This advantage has made it the number 1 exporter of goods and services all over the world.

\section{Data and Methodology}

For the purpose of this research, we have collected the data of bimonthly exports of Vietnam and China to the United States for the year 2019.

From this data, we are going to calculate the correlation between the exports of China to that of Vietnam. Thereafter, we are also going to calculate the correlation between the exports of China and Vietnam during the period when the United States imposed sanctions on Chinese goods and took them down.

\section{Objectives of the Research}

The following are the objectives of the research-

1) To understand whether there is correlation between fall in exports of China and rise in exports of Vietnam to the United States during the sanction period.

2) To understand whether this correlation persists even before and after the sanction period imposed by the United States.

Null and Alternative Hypothesis 


\section{PRIMARY HYPOTHESIS}

$\mathrm{H}_{0}$ : There is no correlation between exports of China and exports of Vietnam to the United States during the sanction period

$\mathrm{H}_{1}$ : There is correlation between exports of China and exports of Vietnam to the United States during the sanction period

Independent Variable: Exports of Vietnam to the United States

Dependent Variable: Exports of China to the United States

\section{SECONDARY HYPOTHESIS}

$\mathrm{H}_{0}$ : There is no correlation between exports of China and exports of Vietnam to the United States through the entire year

$\mathrm{H}_{1}$ : There is correlation between exports of China and exports of Vietnam to the United States throughout the entire year

Independent Variable: Exports of Vietnam to the United States

Dependent Variable: Exports of China to the United States

NOTE: From hereon the exports from China/Vietnam means the same as exports from China/Vietnam to United States.

\section{Time Series Analysis}

For the purpose of this research, we have considered the exports(to United States) data of China and Vietnam during 2019 from tradingeconomics.com.

For the purpose of this research, we have separately analysed the data for both the economies before the imposition of sanctions by the United States on China and during the imposition of sanctions in order to compare the data for exports and identify trends between the two(if any).

\section{Identification of trend of exports}

In this section of the paper, we have compared the exports data for China and Vietnam to the United States before and after the imposition of duties on China by the United States. 
International Journal of Social Science and Economic Research

ISSN: $2455-8834$

Volume:06, Issue:07 "July 2021"

Figure 1:Exports from (a)Vietnam and (b)China before the imposition of duties by the US government

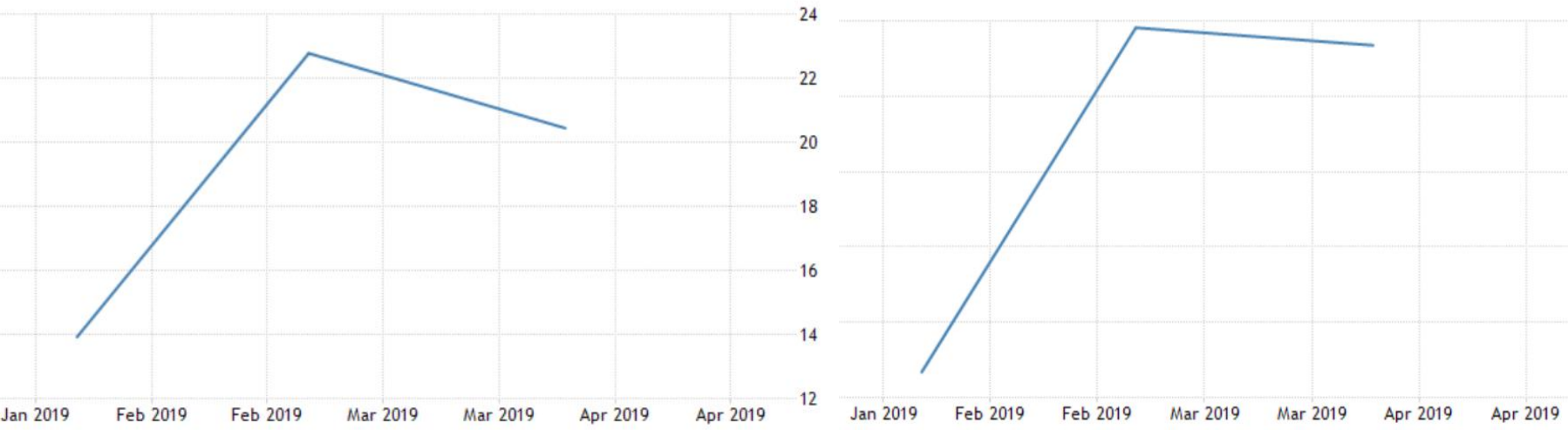

As shown in the figures above, the quantity of exports to United States have been on a rise in both the countries until February 2019 after which they start to decrease but not at a very high rate.

Figure 2:Exports from (a)Vietnam and (b)China after the imposition of duties by the US government

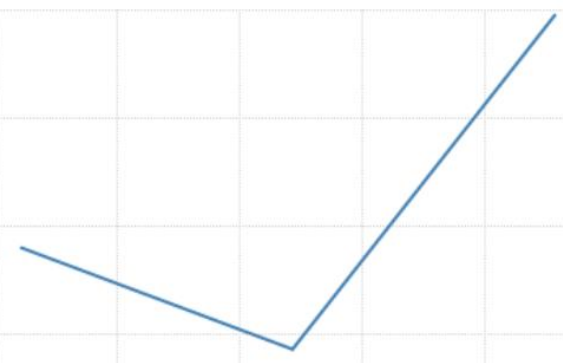

Apr 2019 May $2019 \quad$ May $2019 \quad$ Jun $2019 \quad$ Jun $2019 \quad$ Jul $2019 \quad$ Jul 2019
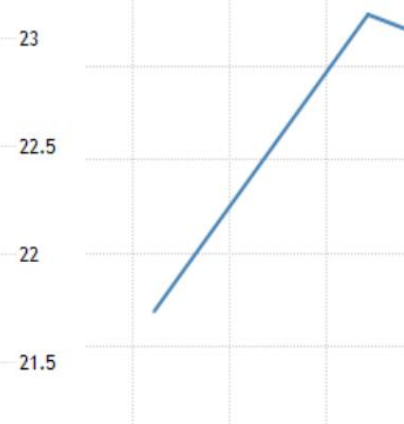

As shown in the figures above, the quantity of exports to United States have been on a rise at a very high rate in Vietnam. However, it is not the same for China as the quantity of exports have been on a steep decline as shown in the diagram.

This, in turn, shows the impact of shift of comparative advantage from China to Vietnam. As a result, the importers from United States shifted their demand from China to Vietnam where the prices of commodities are much lower. As a result, the number of exports rise in case of Vietnam and fall in case of China. 
International Journal of Social Science and Economic Research

ISSN: 2455-8834

Volume:06, Issue:07 "July 2021"

\section{Data Analysis and Results}

We have obtained the data from E-Views by estimating the regression equation of exports from China on exports from Vietnam (both to United States). We have estimated separate regression equations for:

(a) During period of Sanction imposition by the United States on China

(b) During the year 2019

The results from our calculations are as follows:

Table 1:Regression results of Chinese exports on Vietnamese exports during the sanction period

Dependent Variable: CHINA

Method: Least Squares

Date: 07/02/21 Time: 19:11

Sample: 2019M04 2019M09

Included observations: 6

\begin{tabular}{lrlll}
\hline \hline \multicolumn{1}{c}{ Variable } & Coefficient & Std. Error & t-Statistic & Prob. \\
\hline \hline \multicolumn{1}{c}{ C } & 255.4762 & 125.8041 & 2.030746 & 0.1121 \\
\multicolumn{1}{c}{ VIETNAM } & 5.034014 & 5.513562 & 0.913024 & 0.4129 \\
\hline \hline R-squared & 0.172462 & Mean dependent var & 370.0000 \\
Adjusted R-squared & -0.034423 & S.D. dependent var & 23.23790 \\
S.E. of regression & 23.63448 & Akaike info criterion & 9.424492 \\
Sum squared resid & 2234.354 & Schwarz criterion & 9.355078 \\
Log likelihood & -26.27347 & Hannan-Quinn criter. & 9.146624 \\
F-statistic & 0.833612 & Durbin-Watson stat & 1.322053 \\
Prob(F-statistic) & 0.412883 & & & \\
\hline \hline
\end{tabular}


International Journal of Social Science and Economic Research

ISSN: 2455-8834

Volume:06, Issue:07 "July 2021"

Table 2:Regression results of Chinese exports on Vietnamese exports during the year 2019

\begin{tabular}{|c|c|c|c|c|}
\hline \multicolumn{5}{|c|}{$\begin{array}{l}\text { Dependent Variable: CHINA } \\
\text { Method: Least Squares } \\
\text { Date: 07/02/21 Time: } 19: 06 \\
\text { Sample: 2019M01 2019M12 } \\
\text { Included observations: } 12\end{array}$} \\
\hline Variable & Coefficient & Std. Error & t-Statistic & Prob. \\
\hline & 62.21215 & 56.47005 & 1.101684 & 0.2964 \\
\hline VIETNAM & 13.05077 & 2.537286 & 5.143595 & 0.0004 \\
\hline R-squared & 0.725701 & \multicolumn{2}{|c|}{ Mean dependent var } & 350.4167 \\
\hline Adjusted R-squared & 0.698271 & \multicolumn{2}{|c|}{ S.D. dependent var } & 44.28515 \\
\hline S.E. of regression & 24.32577 & \multirow{2}{*}{\multicolumn{2}{|c|}{ Akaike info criterion }} & 9.371961 \\
\hline Sum squared resid & 5917.430 & & & 9.452779 \\
\hline Log likelihood & -54.23177 & \multicolumn{2}{|c|}{$\begin{array}{l}\text { Schwarz criterion } \\
\text { Hannan-Quinn criter }\end{array}$} & 9.342040 \\
\hline F-statistic & 26.45657 & \multicolumn{2}{|c|}{ Durbin-Watson stat } & 1.232969 \\
\hline Prob(F-statistic) & 0.000435 & & & \\
\hline
\end{tabular}

\section{Interpretation and Conclusion}

Throughout the whole year, at $95 \%$ level of significance, the $t_{\text {calculatedis more than }} t_{\text {critical }}$.

This means that the level of correlation is significant between exports from China and exports from Vietnam during the year 2019.

During the sanction period, one unit of increase in exports from Vietnam to United States, on average, leads to decrease of 5 units of exports from China to United States. However, at 95\%

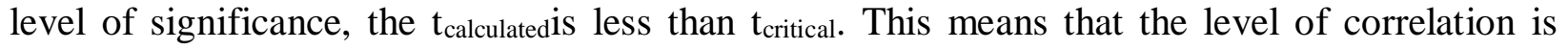
insignificant between exports from China and exports from Vietnam.

During the year 2019, one unit of increase in exports from Vietnam to United States, on average, leads to an increase of 13 units of exports from China to United States.

This suggests that during the sanction period, there is a negative relation between Chinese and Vietnam exports. However, during the whole year, the relation between Chinese and Vietnamese exports is positive. This suggests that there are two effects:

1) The comparative advantage does not lead to a fall in exports of either of the two economies. 
International Journal of Social Science and Economic Research

ISSN: 2455-8834

Volume:06, Issue:07 "July 2021"

2) The positive relation throughout the year is stronger than the negative relation during the sanction period.

This means that, despite the transfer of comparative advantage from China to Vietnam during the sanction period, once the period expired, China restored its comparative advantage. However, this restoration of comparative advantage does not negatively affect the Vietnamese economy as its exports continue to increase.

\section{Overall Conclusion and Discussion}

The Republic of China had a comparative advantage over United States in terms of production of computers and electronic equipment. This comparative advantage arose because of availability of cheaper labour in the Chinese economy. This led to a situation wherein the average cost curve of China was lower than that of the United States.

Figure 3

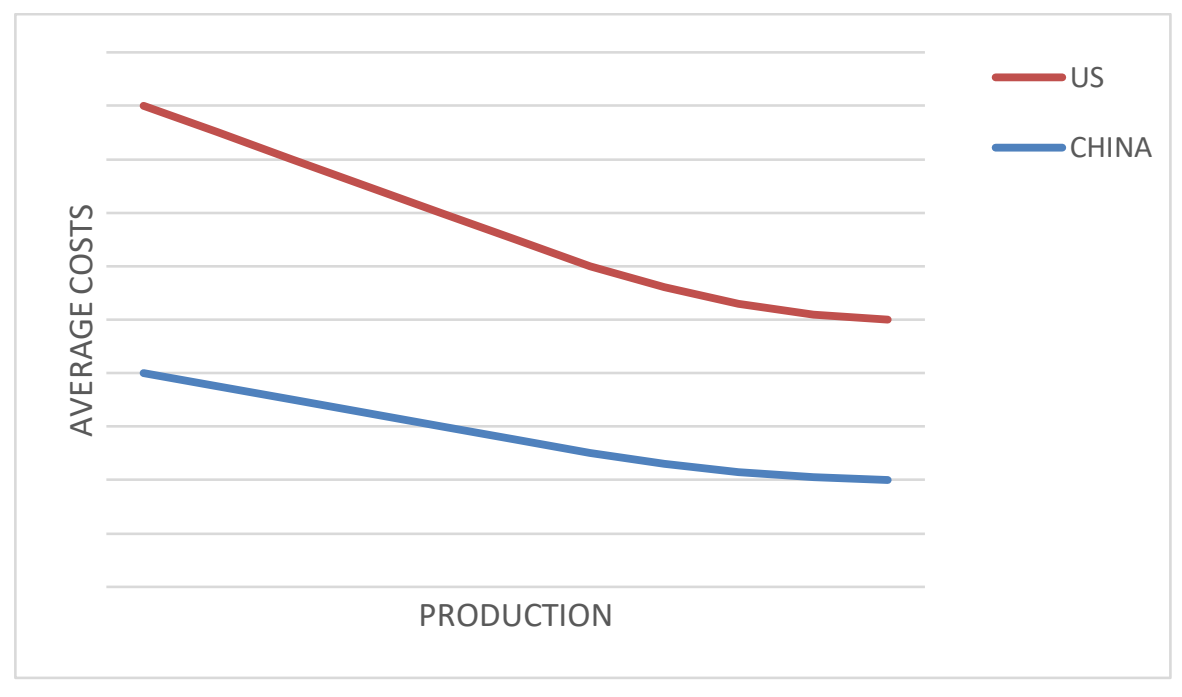

As shown in the Figure 3, the average cost curves of both countries are downward sloping. The Average cost curve of China is represented by the red line and that of United States is represented by the green line. The price and quantity in the market in represented by $\mathrm{P}_{\mathrm{o}}$ and $\mathrm{Q}_{\mathrm{o}}$. This is the situation before the Trump government imposed any sanctions against China. 
International Journal of Social Science and Economic Research

ISSN: 2455-8834

Volume:06, Issue:07 "July 2021"

\section{Figure 4}

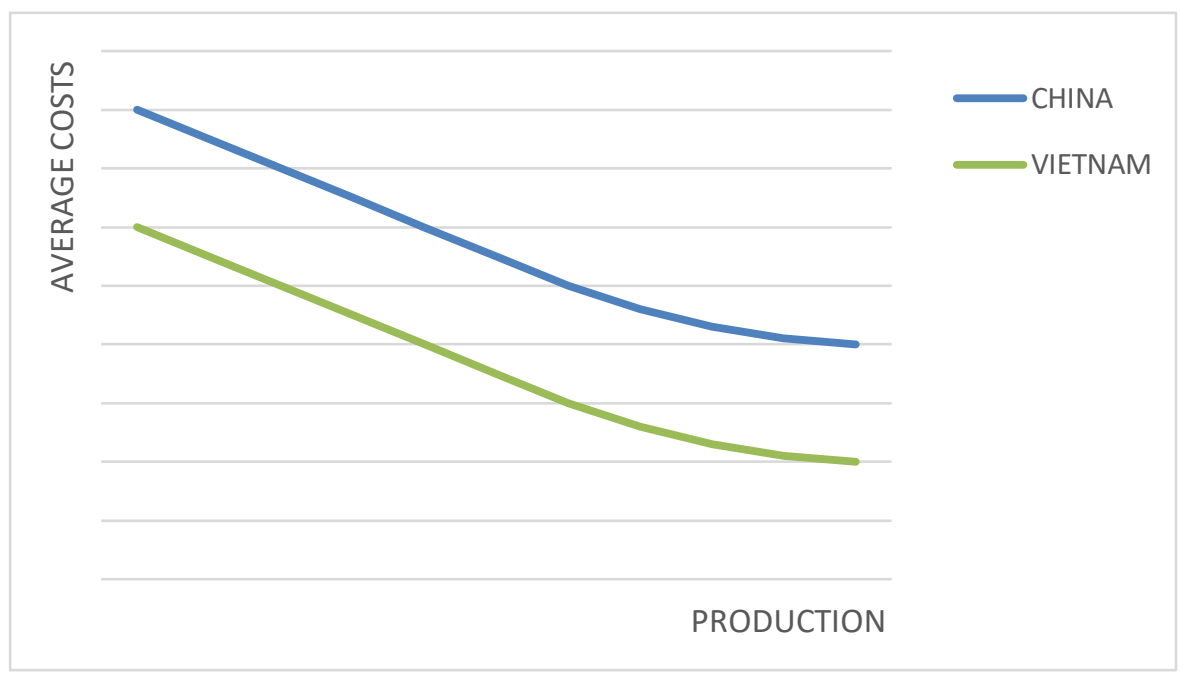

Now, let us move to Figure 4.As shown in the figure, the average cost curve of Vietnam lies below China and the average cost curves of both countries are downward sloping. This suggests that Vietnam has much cheaper labour in comparison to China for production of computers and electronic equipment. However, this does not turn into comparative advantage particularly because the quantity of production and price at which it sold is fixed by China at $\mathrm{Q}_{o}$ and $\mathrm{P}_{\mathrm{o}}$ respectively. This causes Vietnam to initially produce the commodity at a much higher cost than the price at which it can be sold. As a result, China continues to be the supplier to the world because of comparative advantage resulting from historical reasons. This situation is a scenario before the sanctions imposed by United States on China.

Figure 5

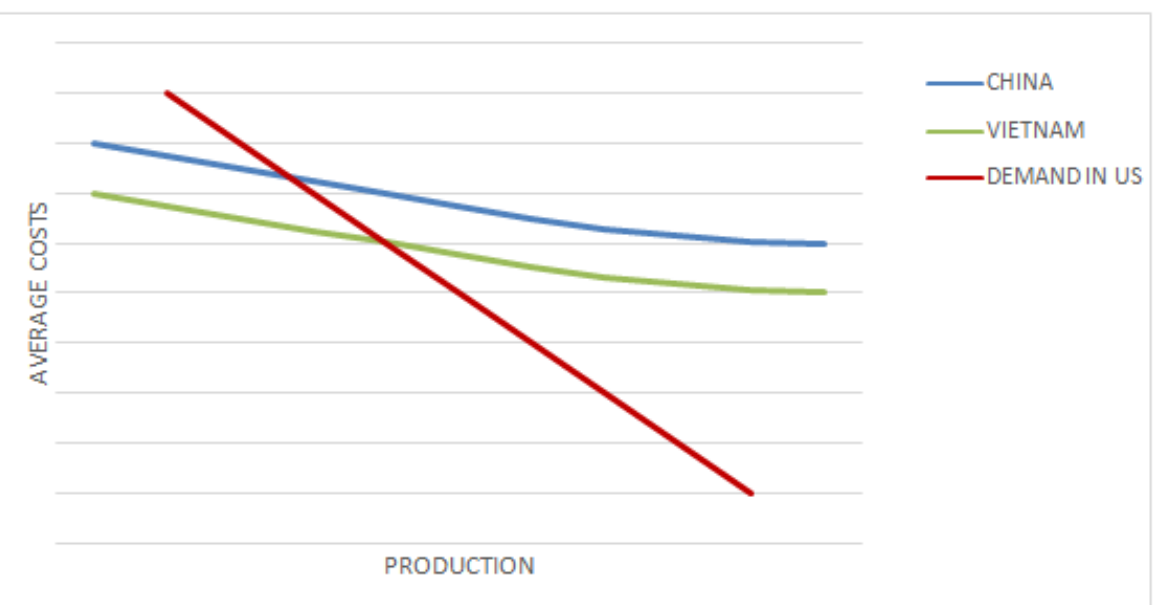


International Journal of Social Science and Economic Research

ISSN: 2455-8834

Volume:06, Issue:07 "July 2021"

After the imposition of sanctions on China, the buyers from United States have a choice between price $\mathrm{P}_{0}+\mathrm{t}$ (sold by China) and $\mathrm{P}_{1}$ (sold by Vietnam). This situation is represented in the Figure 5 .

As a result, this leads to two effects:

1) The importers from United States start importing from Vietnam instead of China.

2) The existing producers in China shifted their production plants to Vietnam.

Due to this situation, the buyers from the United States find it cheaper to import from Vietnam as compared to China. Moreover, the quantity produced by China no longer remains fixed due to shift of production plants from China to Vietnam. As a result, Vietnam can now produce at a much lower price than that of China. Therefore, there is a shift in comparative advantage from China to Vietnam as shown in the diagram.

However, once the sanction period came to an end, the comparative advantage return to China as shown in our regression model. However, this did not have a negative impact on Vietnam as their exports continued to grow.

This in turn, proves that the sanctions imposed by the United States on China led to transfer of comparative advantage from the latter to Vietnam where the labour (and in turn the average costs) were much lower than that of China despite its historical advantage. However, this advantage was only temporary as China regained its exports once the sanction period came to an end.

\section{Acknowledgement}

We would like to thank our supervisor, Prof (Assistant) Mr Puneet Arora, under whose guidance we were able to complete this research. His expertise was crucial in formulating our research questions and methodology. He also helped us to make our research more insightful through his invaluable and constant feedback throughout our research.

\section{References}

1. Ricardo, David. 1817. "Theory of Comparative Advantage," Principles of Political Economy and Taxation.

2. Keesing, DB. 1965. "Labour skills and international trade evaluating many trade flows with a single measuring device." The Review of Economics and Statistics.

3. Wood, A. 1994. "Give Heckscher and Ohlin A chance", WeltwirtschaftlichesArchive 130(March): 20-49. 
International Journal of Social Science and Economic Research

ISSN: 2455-8834

Volume:06, Issue:07 "July 2021"

4. Kiel. Mao,Haiou. Gorg,Holger. "Impact of US-China Trade", Institute of World Economy.

5. Suisheng, Z. Guo, D. 2019.“A New Cold War? Causes and Future of the Emerging USChina Rivalry”. Vestnik RUDN. International Relations, 19(1), 9-21.

6. Carnegie, A. 2018. “Trump's Trade War Escalates," https://www.foreignaffairs.com/articles/2018-06-25/trumps-trade-war-escalates

7. Grossman, G.M.Helpman, E. 1995.“Trade wars and trade talks," Journal of Political Economy, 103(4), 675-708

8. Chunding, L. Chuantian, H. Chuangwei, L. 2018. "Economic Impacts of the Possible China-US Trade War,” Emerging Markets Finance and Trade, 54(7), 1557-1577.

9. Vinogradov, A.O. Salitsky, A.I. Semenova, N.K. 2019."US-China Economic Confrontation: Ideology, Chronology, Meaning. Vestnik RUDN.” International Relations, 19(1), 35-46.

10. Kapustina, L.Lipková, L.Silin, Y. and Drevalev, A. 2020. "US-China Trade War: Causes and Outcomes,'SHS Web of Conferences 73, 01012.

\section{Appendix}

Table 3: China and Vietnam exports to United States in 2019

\begin{tabular}{|l|r|r|}
\hline MONTH & \multicolumn{1}{|l|}{ CHIN } & VIETNAM \\
\hline JAN & 360 & 22 \\
\hline FEB & 225 & 14 \\
\hline MAR & 330 & 23 \\
\hline APR & 325 & 20.5 \\
\hline MAY & 375 & 22 \\
\hline JUN & 390 & 21.5 \\
\hline JUL & 385 & 23 \\
\hline AUG & 375 & 26 \\
\hline SEPT & 370 & 23.5 \\
\hline OCT & 365 & 24 \\
\hline NOV & 360 & 22.5 \\
\hline DEC & 345 & \\
\hline
\end{tabular}

